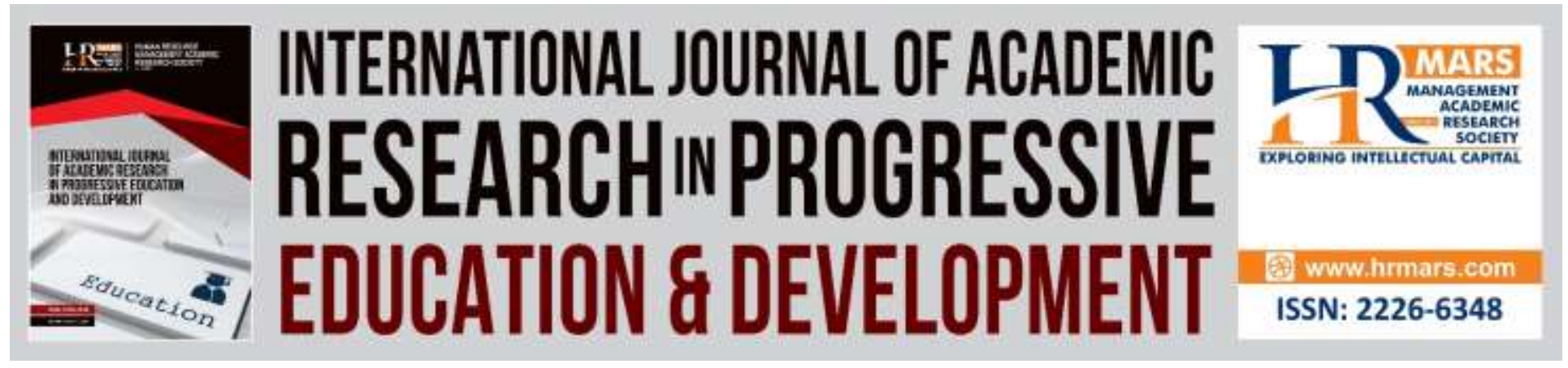

\title{
A Comparative Study between the Middle Eastern and China EFL Learners in Academic Writing
}

\author{
Lai Ke Ying, Or-Kan, Soh
}

To Link this Article: http://dx.doi.org/10.6007/IJARPED/v8-i3/6371

DOI: $10.6007 /$ IJARPED/v8-i3/6371

Received: 19 July 2019, Revised: 19 August 2019, Accepted: 02 September 2019

Published Online: 20 September, 2019

In-Text Citation: (Ying \& Or-Kan, 2019)

To Cite this Article: Ying, L. K., \& Or-Kan, S. (2019). A Comparative Study between the Middle Eastern and China EFL Learners in Academic Writing. International Journal of Academic Research in Progressive Education \&

Development, 8(3), 201-223.

\section{Copyright: (C) 2019 The Author(s)}

Published by Human Resource Management Academic Research Society (www.hrmars.com)

This article is published under the Creative Commons Attribution (CC BY 4.0) license. Anyone may reproduce, distribute, translate and create derivative works of this article (for both commercial and non-commercial purposes), subject to full attribution to the original publication and authors. The full terms of this license may be seen at: $\underline{\text { http://creativecommons.org/licences/by/4.0/legalcode }}$

Vol. 8(3) 2019, Pg. 201 - 223

Full Terms \& Conditions of access and use can be found at http://hrmars.com/index.php/pages/detail/publication-ethics 


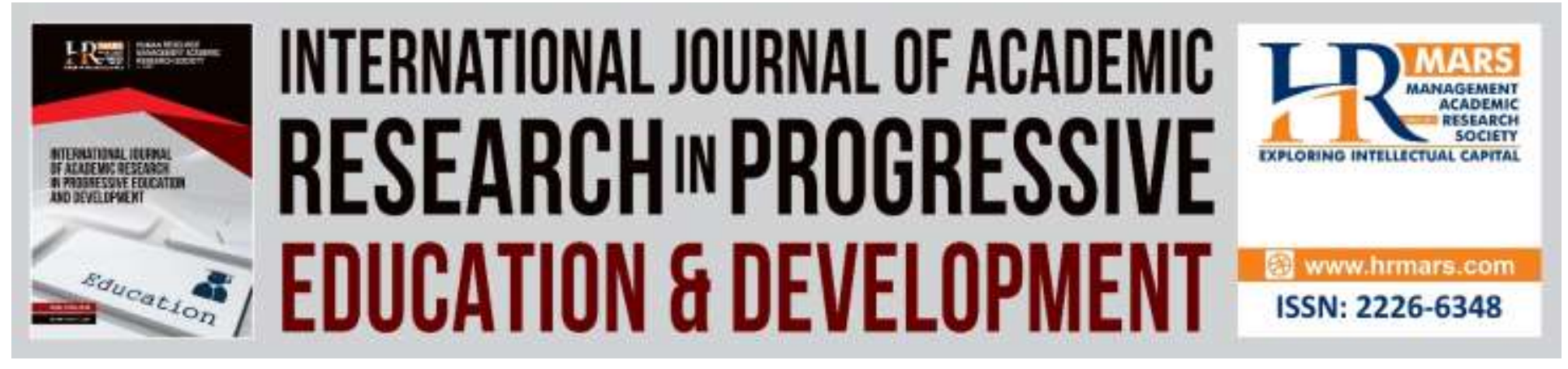

\title{
A Comparative Study between the Middle Eastern and China EFL Learners in Academic Writing
}

\author{
Lai Ke Ying, Or-Kan, Soh
}

School of Language Studies \& Humanities Universiti Kebangsaan Malaysia (UKM)

\begin{abstract}
The purpose of this study is to identify the differences in academic writing among total 20 of the Middle Eastern and China EFL learners respectively at The National University of Malaysia (UKM). Besides, it also helps to determine the writing patterns and perspectives of the Middle Eastern and China EFL learners in academic writing. In addition, this study also investigates the influence of educational level towards Middle Eastern and China EFL learners' writing patterns in academic writing. The instrument used in this study was a set of questionnaires. Moreover, the Statistical Package for Social Sciences (SPSS) is used to analyse the collected data. Findings revealed a slight significance results between the writing patterns of the Middle Eastern and China EFL learners in academic writing. In addition, the perspectives of both EFL learners in academic writing have examined. Nevertheless, it was revealed that educational level influences the writing patterns of Middle Eastern EFL learners but not China EFL learners. In conclusion, this study would thus provide a new insight into these two linguistic groups.
\end{abstract}

\section{Introduction}

It is widely accepted that English has undoubtedly become the language of choice which has been thus identified as an international language (Crystal, 1997). Sidek (2012) stated that English is getting essential especially in the globalised higher education sector. Among English language skills, writing is known as one of the major language skills. Kellogg \& Raulerson (2007) proclaimed that effective writing skills are crucial in higher education because proficiency in writing is invaluable to assist academic performance.

However, it is obvious that among four English skills, writing has been identified as the most difficult skills as writing has its own challenges especially for English as a Second Language (ESL) or English as a Foreign Language (EFL) learners in university level. Ariyanti (2017) claimed that writing seems never been so easy especially for EFL learners as it is demanding to write in a foreign language because it is a complex, challenging and difficult process due to the reason that writers are expected to produce written products that are accurately in syntactic and acceptable in semantics where it is particularly described in the case of foreign language learners (Alsamadani, 2010). Casanave (2003) thus claimed that non-native speakers faced difficulties in 
English writing because they are expected to produce native-like written samples. Generally, EFL learners appeared to face many problems in organizing their ideas, form coherent and wellreasoned writing content and providing supportive evidence. Therefore, the ability to write academic text effectively is important especially required for EFL learners as academic writing acts as an indispensable part of it that often used by learners at a higher educational level. The keystone of higher education relied on the quality research especially during tertiary level as tertiary learners need to present their research paper. Thus, this study will focus on the educational level of EFL learners as it is vitally important for them to understand their writing patterns that affect their writing and empower it because every learner has their own writing patterns according to their own cultural dimension.

Writing patterns also recognized as cultural thought patterns. Correspondingly, Kaplan (1966) declared about the compositions of EFL learners and the assessment towards the cultural contexts from the origins of learners. He thus proposed a well-known and controversial article on contrastive rhetoric about "Cultural thought patterns in inter-cultural education" by claiming that "each language group shapes a paragraph order unique to itself according to its own culture". Thereby, different writing patterns are shown by the texts written in different languages as a result of differences in the cultural dimension. Kaplan's 1966 article emphasizes on academic writing in different cultural settings. He made a hypothesis that the academic writing by EFL learners resulted by their first language, which is named as Doodles Text (Kaplan, 1987). He declared that different cultural thought patterns that reflected the way they organize writing are influenced by different languages of learners. Therefore, a diagram of five cultural thought patterns has been put forward in which English language discourse pattern is delineated as a straight line which indicates that the ideas is direct, linear and does not off topic whereas Asian discourse pattern is depicted as a spiral in which characterized by circularly with indirectly approached a topic and came to the main point at the end, Arab-Semitic pattern characterized by a complex series of parallel constructions, with the first idea completed in the second part, Romance language pattern is similar to Russian language pattern. Nevertheless, Romance language pattern demonstrates a digressive style and the introduction of extraneous material whereas Russian language pattern consists of more subordinate elements. Kaplan indicated that culture determines the ideas presented by EFL learners in their academic writing. In addition, Liebman (1992) illustrated that the writing patterns of EFL learners influenced by their first language which has thus affected them in their academic writing as they shifted their preferred discourse patterns in academic writing.

In brief, the present study focuses on two linguistic groups, Middle Eastern and China EFL learners that study at The National University of Malaysia (UKM). Hence, this study is aimed to compare the writing patterns and perspectives of both the Middle Eastern and China EFL learners in academic writing. Additionally, the intent of the present study is to compare the educational level with their writing patterns in order to find out significant results between them. 
INTERNATIONAL JOURNAL OF ACADEMIC RESEARCH IN PROGRESSIVE EDUCATION AND DEVELOPMENT

Vol. 8, No. 3, 2019, E-ISSN: 2226-6348 @ 2019 HRMARS

\section{Challenges for EFL Learners in Academic Writing}

Taking into account that writing in a second or foreign language is challenging (Bowen and Mark, 1994, Kroll, 1990, Smith, 2001; Hyland, 2003). It has been identified as a difficult skill because writers need to balance the important elements in their academic writing such as organization, vocabulary, and grammar. Furthermore, it is difficult especially for non-native speakers such as ESL or EFL learners because they are expected to produce written products like native speakers and need to acquire the mastery of written academic English. Additionally, they have been discovered to have hardship in composing their academic writing due to the influence of their cultural background. In 1966, Kaplan proposed a theory, contrastive rhetoric, by stating that each linguistic group has a paragraph order that is unique to itself which is influenced by its own culture. Pesola (1991) thus claimed that language and culture are in a close relationship and culture shapes the use of language. In addition, Quinn (2012) illustrated that the writing patterns found in contrastive rhetoric can benefit EFL learners' academic writing. Therefore, a study will be conducted in comparing the writing patterns of EFL learners at The National University of Malaysia (UKM). However, according to the previous studies, it has been found out that there is much past research focused on the writing patterns of some linguistic groups such as Japanese and English, but it is difficult to find a significant investigation into the Middle Eastern and China EFL learners at the same time. Correspondingly, due to the shortage of investigation to these two linguistic group, it thus led to the limited research on comparing their writing patterns and examine their perspectives in academic writing.

Apart from that, as a result of an indeed significant relationship among educational level and cultural participation are assessed, educational level is identified as one of the elements in the cultural background (Bakker, 1985; Ganzeboom, 1989). Therefore, the educational level of EFL learners will be in-depth discussion to investigate whether it affects them in academic writing because the educational attainment greatly influences a person and thus leads them to compose in different writing patterns. However, due to the limited study done in the past, this study will be concentrated to fill in the gap in determining the educational level of EFL learners from Middle Eastern and China and their writing patterns in academic writing.

Following these lines of inquiry, the current study is aimed to compare the writing patterns and examine the perspectives of Middle Eastern and China EFL learners in their academic writing. Additionally, this study is carried out to investigate the educational level would facilitate the writing patterns of these two linguistic groups, Middle Eastern and China EFL learners in their academic writing. In a nutshell, the underlying motivation of this study is to explore the differences between the writing patterns, perspectives and educational level by both the Middle Eastern and China EFL learners in UKM.

\section{Contrastive Rhetoric Applied by Middle Eastern Learners}

Arabic was among the first language studied in the field of contrastive rhetoric in Kaplan's (1966) seminal study. In 1966, Kaplan conducted a study and he discovered that Middle Eastern learners used paragraph development based on a complex series of parallel constructions which is both positive and negative. According to Sa'adeddin (1989), he discovered that the organization of the 
Middle Eastern text is "circular and non-cumulative" and "Middle Eastern writers come to the same point two or three times from different angles so that a native English is expected to be linear, coherent and concise". An argument was made by Derrick and Gmuca (1985) that there is no room for doubt in Middle Eastern learners' writing.

Kaplan declared that Middle Eastern writers' writing patterns are transferring their ideas from their mother tongue into English writing as early in 1966. Besides, Middle Eastern EFL learners often think and prepare their ideas in their native language and then translate them into English (Khuwaileh \& Shoumali, 2000). In addition, Al-Khatib (2000) conducted a study about writing personal letters in English by Middle Eastern learners. Learners transferred the Middle Eastern style of writing personal letters into English and their usage of language reflects the Middle Eastern cultural thought patterns which have been characterized by length and indirectness. He thus stated that the introductions are lengthy in terms of questioning which is not concise and are not to the point. Middle Eastern learners used to include questions about the addressee's health, personal life, and family whereas, in contrast, native English speakers do not include such questions in their personal letters.

Al-Khatib (2000) summarized that the writing style by these subjects is apparently influenced by their sociolinguistics backgrounds. Feghali (1997) made review research and she concluded that Middle Eastern learners share the common features of communicative style which may conflict with other language styles such as repetition, indirectness, elaborateness, and effectiveness which indicates that intuitive-affective style of emotional appeal. Many researchers who studied Middle Eastern EFL learners' essays noted in their studies that Middle Eastern EFL learners have always been accused of overusing repetition in their writing. Moreover, Middle Eastern newspaper texts demonstrate that Middle Eastern argumentative texts manifest repetition as an argumentative strategy at all three levels (Swales \& Mustafa, 1984). Additionally, the repetition feature in Middle Eastern EFL learners' essays seems endless awkward and ambiguous to English native speakers (Ostler, 1987). Therefore, Thompson-Panos (1983) stated that in both spoken and written Middle Eastern, the devices used to illustrate ideas clearly are repetition, increased use of the superlative and frequent rewording and restatement. Middle Eastern EFL learners have thoughts about their ideas would be clear if they use repetition in their writing as it indicated that they emphasized on the point. Furthermore, redundancy is examined as the positive aspect in Middle Eastern writing because it reflected about the person mastered the language that he or she can play with the language. Thus, when Middle Eastern learners write in English, they will unconsciously transfer this phenomenon.

Besides, Feghali (1997) also claimed that the characteristics of Middle Eastern learners are tending to use rich and expressive language. In addition, exaggeration and assertion also are the rhetorical patterns of Middle Eastern communicative style. Hence, Middle Eastern learners tend to exaggerate and over-assert things to be believed and understood. According to Al-Khatib, he proclaimed that persuasion in Arabic is based on three major modes which are trustworthiness, argumentation, and appeal to emotions. There are Middle Eastern learners assert their trustworthy and reliability to convince the audience and they also attempt to persuade others by making an argument and supporting it with convincing reason. Additionally, they may appeal to 
the audience emotionally through the usage of proverbs and wisdom such as some Qura'nic verse.

\section{Contrastive Rhetoric Applied by Chinese Learners}

Kaplan (1966) illustrated English exposition structure as being linear and Oriental exposition as being circular in his famous "doodles" diagram. This view has consequently provoked as he made an argument that Chinese, as well as Oriental writing, is indirect. However, he readjusted his position and regretted his oversimplification and overstatement of differences between languages when he reviewed his previous study in 1987. Furthermore, he emphasized that contrastive rhetoric is "to describe ways in which written texts operate in larger cultural contexts" (Grabe \& Kaplan, 1989).

Two traditional Chinese rhetorical patterns have been widely discussed which were "ba gu wen" (eight-legged essay) and "qi cheng zhuan he". Matalene (1985) proclaimed that eight-legged essay became the significant written genre at that period under China's feudal dynasties from the Fifteenth to the Nineteenth Centuries. She also stated that a thesis did not provide by the opening lines of the Chinese eight-legged essay. This discourse style prefers to show a topic then to steadily unravel it by building information before expressing the important information. Therefore, the major written genre of the time is using the format of the eight-legged essay. Kaplan $(1972 ; 1983 ; 1987 ; 1988)$ implied that the purportedly circular nature of Chinese rhetoric under the effect of eight-legged civil service exam essay and he presented a discourse style of verbalizing around the central subject rather than assaulting it directly. Thus, a variety of indirectly related views is demonstrated through a Chinese model of delivering ideas.

Kaplan (1966) conducted research on investigating the shape of Chinese discourse, which is indirect, implicit and circular. Hinds (1990) revealed that the message structure of putting supporting details or reasons first before the main point is referred by an inductive pattern of topic introduction. The objective of a text is to proclaim the truth and arrange the argument such that it can be easily and harmoniously agreed upon by referring to communal and traditional wisdom. In the introduction of the text, Chinese writers need to "humble' themselves. Therefore, good Chinese writers may recommend instead of mentioning it directly since to convey a viewpoint overtly is seen as too individualistic. In the opening sections of text, they tend to avoid a direct statement of the thesis. The thesis statement is stated towards the middle of the text, towards the end or perhaps certainly not clear at all. Kaplan thus calls this approach as "indirection" which indicates that the discourse development follows a pattern of turning and turning in a widening gyre. It can be further illustrated that the loops revolve around the topic and view it from a variety of positions but do not address it directly (p.10).

Apart from that, Connor (1996) illustrated the outlines of the traditional Chinese rhetorical style. First, he claimed that it begins with one's evidence before developing it. After finish developing it, the idea turns to a sub-theme where there is a connection, but the point does not directly connect to the major theme. Third, a conclusion is constructed after bringing all the ideas together. Finally, return to discuss the main idea as this part usually give intention for reader to 
reinforce the theme, but it seems like odd repetition for English readers if the main idea is not explicitly stated. Chinese rhetoric moves from specific which refers to evidence or sub-points to general which implies about inferences to a thesis. In addition, a verbose and indirect expression is considered an artistic and aesthetic way to express respect in traditional Chinese culture. It is because, in Chinese societies, readers are expected to work hard to figure out the meaning of an article as stating things too explicitly is an insult to the reader and there must be a room left for readers' interpretation. English writing conversely expects that the burden of clarity will be assumed by writers.

Additionally, it is said that the Chinese style of writing is "qi-cheng-zhuan-he" which is commonly glossed as 'beginning', 'development', 'turn', 'conclusion'. Nevertheless, as stated by Connor (1996), he illustrated that 'qi' refers to open or to start but does not indicate to state one's thesis statement whereas 'cheng' means to carry on and to sustain while 'zhuan' reveals to turn and to look at the problem from another angle and 'he' means to conclude whereby the writer's real opinion is established or hinted at. It is thereby showed that Chinese writers tend to write their main idea at the end of their essays, which refers to a conclusion. Gu (1992) thus explained that "qi-cheng-zhuan-he" does not have a thesis statement relating to the topic at the beginning of the text and instead the theme may occur in any paragraph depending on the author's needs. Furthermore, Cai (1993) who was a follower of Kaplan's work proposed that eight-legged essay is still a powerful principle for many Chinese learners whereas "qi-cheng-zhuan-he" is often employed by Chinese learners to organize paragraphs in writing essays. Moreover, he realized that Chinese learners tended to avoid expressing their personal views freely and directly in their essays.

Matalene (1985) as an American Writing Teacher in China has shown that she used parts of English composition written by Chinese learners and translations of various Chinese texts to explain the characteristics of Chinese rhetoric. Nevertheless, Matalene, unlike Kaplan, did not dwell just on formal aspects of rhetoric such as the forms that paragraph takes but focused on discussing Chinese writers' reliance on remembrance and administration of set phrases and textual forms to accentuate on group values over individualistic goals. She summarized that the inadequacy of Chinese rhetoric about argumentative coherence because of its dependence on references to history, tradition, and authorities. Other researchers also expressed their disagreement with Kaplan's hypothesis. They refused the overly simplistic explanation offered by Kaplan in his early writings about the effect of eight-legged essay on Chinese ESL or EFL writing. Mohan and Lo (1985) disputed Kaplan's claim of the importance of the eight-legged essay in Chinese writing and argued that eight-legged essay is the only one variation used in traditional "wen-yan" (old prose) style. It was used in hundreds of years ago by government officers. In fact, the "bai-hua" style has replaced "wen-yan" pattern. Hence, it is believed that Chinese writers tend to use the rhetoric pattern of "qi-cheng-zhuan-he" instead of an eight-legged essay.

\section{Research Design}

According to Parahoo (1997), a research design is a proposal that illustrates how, when and where data are to be collected and it also refers to an answer to the research question. The 
research approach adopts a quantitative method to collect data. A survey questionnaire becomes the main research tool as it provides useful information which is the consistency and precision in terms of the wording of questions and the answer can be processed easily in the usage of the questionnaire (Denscombe, 1998).

The quantitative methodology will be utilized in this research and it enables the researcher to collect reliable and accurate data (Leedy, 2001). It is because as data is collected, analysed and presented in numbers, the results obtained will be extremely reliable because they present an honest picture of the conducted research without discrepancies.

The survey research method will be the research design for this study. The respondents are generally expected to answer close-ended questions in 20 minutes for the researcher to obtain a more complete picture of respondents' perspectives in academic writing. It involves flexible questioning designed to uncover basic features the individual's thinking in academic writing.

Apart from that, pilot study designed by the researcher in which each question will be read aloud by the researcher meanwhile the Middle Eastern and China EFL learners can ask questions regarding any unclear ideas as it might be the definition of the certain words or what is the important message that trying to convey in the questions.

\section{Sample Population}

The targeted population of this study is EFL learners at The National University of Malaysia (UKM). The required sample is 20 the Middle Eastern and 20 China EFL learners for filling in the questionnaires. While for the pilot study, it will have a total of $10 \mathrm{EFL}$ learners in UKM in which 5 of them are from the Middle Eastern and another 5 from China. The sample of learners for this study is selected using simple random sampling by country (the Middle Eastern and China). Simple random sampling refers to each member has an equal probability of being chosen in the subset as it implies an unbiased representation of a group. This method could ease of use and accuracy of representation as it enables the researcher to obtain an adequate number of respondents even though they study different course and have different educational level, yet they come from the selected country which is Middle Eastern and China.

\section{Research Instruments \\ Questionnaire}

Questionnaire refers to a set of questions that have been constructed for the objective of obtaining information from respondents. It is a very convenient way of collecting useful comparable data from a number of individuals because it can produce valid and meaningful results. The questionnaire will be answered in English and was given to each targeted respondent.

As shown in Appendix 1, the questionnaire will be divided into 3 sections, in which Section A concerns on respondents' demographic information which included age, gender, citizenship, 
English test that have taken by respondents before enrolling in UKM, respondents' educational level, faculty and course.

Section B of the questionnaire consists of 25 questions based on Likert-Scale ranging from "Strongly Disagree" to "Strongly Agree". This section focuses on respondents' writing patterns in which each 5 questions are designed according to Five Cultural Thought Patterns which is Asian Discourse Pattern, English Language Pattern, Arab Semitic Pattern, Romance Language Pattern and Russian Language Pattern. In this part, each respondent is required to rate on a 4-point scale to illustrate their writing patterns in academic writing. Correspondingly, the higher the respondent rate on the writing patterns, it thus indicates the significant result between respondents' writing patterns with their cultures.

Apart from that, section $C$ of the questionnaire emphasizes on respondents' perspectives in academic writing. 5 questions will be mapped out in this section such as the periods of respondents study writing in school, types of writing did the most by respondents, respondents' opinion about the key element by their teachers when grading their papers, frequency of thinking native language in academic writing and the biggest difference between writing in native language and in English. Thus, the viewpoint of respondents in academic writing could be examined in a deeper understanding.

\section{Interviews}

Close-ended questions are defined as a multitude of form and respondents are required to answer types of questions such as dichotomous questions or a set of multiple-choice questions. In this study, multiple-choice-close-ended questions will be designed. The main advantage of close-ended questions are respondents can understand and answer the questions easily by making quick response and thus improves the consistency of responses. Correspondingly, respondents can choose the response that most closely represents their views among a possible set of answers.

\section{Findings}

\section{Writing Patterns of Respondents}

There is a total of 25 questions have designed in the second parts of the questionnaire. It comprised 5 questions according to each pattern. The collected data will be analysed using cross tabulation, which aims to identify the relationship within the not readily apparent data that enables the researcher to gain better and deeper insights.

The questions below are designed according to Asian Discourse Pattern for the researcher to figure out whether respondents especially China respondents are using this pattern in academic writing. 

DEVELOPMENT

Vol. 8, No. 3, 2019, E-ISSN: 2226-6348 @ 2019 HRMARS

\begin{tabular}{|l|c|c|c|c|c|}
\hline $\begin{array}{l}\text { Question 1: Do you } \\
\text { use "qi-cheng- } \\
\text { zhuan-he" } \\
\text { structure while } \\
\text { writing an essay? }\end{array}$ & $\begin{array}{l}\text { Strongly } \\
\text { disagree }\end{array}$ & Disagree & Agree & $\begin{array}{c}\text { Strongly } \\
\text { agree }\end{array}$ & Total \\
\hline Middle Eastern & 0 & 20 & 0 & 0 & 20 \\
\hline China & 2 & 9 & 7 & 2 & 20 \\
\hline
\end{tabular}

Table 1: Usage of "qi-cheng-zhuan-he" structure while writing an essay

Table 1 shows that 20 Middle Eastern respondents (100\%) disagree to use "qi-cheng-zhuan-he" structure while writing English essay. Correspondingly, it indicates that all the Middle Eastern respondents do not utilize the structure of beginning-development-turn-conclusion in their English writing.

On the other hand, China respondents perform a similar percentage in which 9 of them disagree to adopt this structure in their English writing. However, unlike the 9 China respondents, 7 of them agree to employ this structure while writing an English essay. Jia (1997) stated that "qicheng-zhuan-he" or named as four-part structure has become the rhetorical framework dictating Chinese writing such as contemporary writing of different genres which is narrative, argumentative, expository, and persuasive genres as it is found as the best expression for indirectness or inductive approach in communication and patterns of thinking. Her statement can thus describe about the agreement from certain China respondents.

\begin{tabular}{|l|c|c|c|c|c|}
\hline $\begin{array}{l}\text { Question 2: Do you like } \\
\text { to use repetitive } \\
\text { method while writing }\end{array}$ & $\begin{array}{l}\text { Strongly } \\
\text { Disagree } \\
\text { an essay in order to } \\
\text { achieve coherence? }\end{array}$ & Disagree & Agree & $\begin{array}{c}\text { Strongly } \\
\text { agree }\end{array}$ & Total \\
\hline Middle Eastern & 0 & 2 & 16 & 2 & 20 \\
\hline China & 0 & 10 & 9 & 1 & 20 \\
\hline
\end{tabular}

Table 2: Usage of repetitive method while writing an essay in order to achieve coherence

Table 2 denotes that Middle Eastern respondents agree that they use repetitiveness to enhance coherence with a total amount of 18 of them highlighted to agree with the results. There are a variety of forms in the Middle Eastern and repetition is operated to serve important functions in a text (Farghal, Shunnaq, Dickins, \& Watson, 1999). For instance, repetition is heavily functioned as it acts as important textual, rhetorical functions and cohesive functions which contribute to the organization of text in the Middle Eastern language and culture.

Apart from that, the finding delivers a big difference between the Middle Eastern and China respondents as this method is used by only 10 China respondents and 9 of them are not engaging in this technique. The agreement is shown by the majority of the China respondents that they believed that in order to achieve cohesion, a variety of repetitive form should be used, and it is 
often applied in non-literal EFL writing by China EFL writers (Hoey \& Zhu, 2001). Moreover, Lian (1993) developed a grammatical repetition whereas Hoey (2001) employed lexical repetition as they discovered that Chinese EFL grammatical repetition for sentence coherence and lexical repetition for both sentence and textual coherence. Grammatical scale concentrates on meaning repetition with intensifiers and self-evident modifiers such as adverbs, adjectives, nouns, or verbs whereas lexical scale adopted for measurement ranges from simple repetition with simple paraphrase to the complex repetition with complex paraphrase. Simple repetition refers to a lexical item which has occurred in a text and it is repeated without making big changes and it is often used the same item except for a very close grammatical paradigm shift from a single noun to the plural form whereas complex repetition points out about two lexical items share a lexical morpheme such as the words discover and discovery.

\begin{tabular}{|l|c|c|c|c|c|}
\hline $\begin{array}{l}\text { Question 3: Do you use } \\
\text { a poetic or } \\
\text { metaphorical format } \\
\text { that relies on the } \\
\text { wisdom of the past in } \\
\text { writing? }\end{array}$ & $\begin{array}{l}\text { Strongly } \\
\text { Disagree }\end{array}$ & Disagree & Agree & $\begin{array}{c}\text { Strongly } \\
\text { agree }\end{array}$ & Total \\
\hline Middle Eastern & 0 & 15 & 4 & 1 & \\
\hline China & 0 & 8 & 11 & 1 & 20 \\
\hline
\end{tabular}

Table 3: Usage of a poetic or metaphorical format that relies on the wisdom of the past in writing

The table above illustrates that the Middle Eastern rarely use the metaphorical format in their writing, hence, it shows 15 of them disagree to adopt it in writing. Nevertheless, there are 11 China respondents agree that they utilize metaphorical format in their writing. Snively (1999) justified that the widespread use of metaphors by China people because they are unwilling to share their feelings directly and they prefer to use metaphors to avoid directness.

\begin{tabular}{|l|c|c|c|c|c|}
\hline $\begin{array}{l}\text { Question 4: Do you } \\
\text { use indirectness } \\
\text { way to construct } \\
\text { the main idea in } \\
\text { your writing? }\end{array}$ & $\begin{array}{l}\text { Strongly } \\
\text { Disagree }\end{array}$ & Disagree & Agree & $\begin{array}{c}\text { Strongly } \\
\text { agree }\end{array}$ & Total \\
\hline Middle Eastern & 0 & 2 & 18 & 0 & 20 \\
\hline China & 2 & 2 & 14 & 2 & 20 \\
\hline
\end{tabular}

Table 4: Usage of indirectness way to construct the main idea in your writing

Table 4 vividly shows that 18 Middle Eastern respondents undertake indirectness method to illustrate their main ideas in writing and only 2 of them do not do the same. As stated by Alsamadani (2010) that Middle Eastern learners usually talk indirectly around the topic regarding 
Vol. 8, No. 3, 2019, E-ISSN: 2226-6348 @ 2019 HRMARS

the phrases before they state the main points which clearly illustrates the obtained result from the respondents regarding this question.

Yet, relatively China respondents ordinarily using indirectness way to form the gist while writing English by showing the results of 14 of them use this method. As claimed by Snively (1999) that indirectness is highly valued in English writing because a person should not straightforward state an opinion because it is considered as impertinent, abrupt and lacking aesthetic qualities.

\begin{tabular}{|l|c|c|c|c|c|}
\hline $\begin{array}{l}\text { Question 5: Do you use } \\
\text { inductive style (make } \\
\text { specific observations to } \\
\text { broad generalizations) } \\
\text { in English essay writing? }\end{array}$ & $\begin{array}{l}\text { Strongly } \\
\text { Disagree }\end{array}$ & Disagree & Agree & $\begin{array}{c}\text { Strongly } \\
\text { agree }\end{array}$ & Total \\
\hline Middle Eastern & 0 & 2 & 13 & 5 & 20 \\
\hline China & 1 & 9 & 7 & 3 & 20 \\
\hline
\end{tabular}

Table 5: Usage of inductive style in English essay writing

Regarding the usage of an inductive style of both the Middle Eastern and China respondents in English essay writing can refer to Table 5. There are 13 Middle Eastern respondents agree to use this style in their English essay writing and only 2 of them disagree of using this. On the contrary, there are 9 China respondents disagree to utilize this pattern of writing and only 7 of them agree about this as China writers tend to write inductively with the main point delayed and implied (Jia, 1997).

\begin{tabular}{|l|c|c|c|c|c|}
\hline $\begin{array}{l}\text { Question 6: Do you use } \\
\text { paragraph essay } \\
\text { organization to write an } \\
\text { essay? }\end{array}$ & $\begin{array}{l}\text { Strongly } \\
\text { Disagree }\end{array}$ & Disagree & Agree & $\begin{array}{c}\text { Strongly } \\
\text { agree }\end{array}$ & Total \\
\hline Middle Eastern & 0 & 13 & 7 & 0 & 20 \\
\hline China & 1 & 5 & 14 & 0 & 20 \\
\hline
\end{tabular}

Table 6: Usage of 5 paragraph essay organization to write an essay

Middle Eastern respondents highlight the highest percentage with 13 of them by disagreeing that they often use five-paragraph essays in writing an essay whereas another 7 of them agree about this statement as shown in Table 6.

Contrarily, China respondents break up a record with 14 of them adopt their English essay with 5 paragraph organization and only 6 of them do not do so. On the other hand, China learners have set a goal for EFL writing practice in the past research as teachers' roles are focusing on linguistic accuracy and discourse patterns whereas students write a paragraph by forming sentences. Liu \& Zhao (2011) thus stated that Chinese discourse is a grammatical, coherent piece of writing with clear and complete thematic information and certain communicative purpose and function. 
INTERNATIONAL JOURNAL OF ACADEMIC RESEARCH IN PROGRESSIVE EDUCATION AND DEVELOPMENT

Vol. 8, No. 3, 2019, E-ISSN: 2226-6348 ㄷ 2019 HRMARS

\begin{tabular}{|l|c|c|c|c|c|}
\hline $\begin{array}{l}\text { Question 7: Are you } \\
\text { able to write an } \\
\text { accuracy and correct } \\
\text { statement? }\end{array}$ & $\begin{array}{l}\text { Strongly } \\
\text { Disagree }\end{array}$ & Disagree & Agree & $\begin{array}{c}\text { Strongly } \\
\text { agree }\end{array}$ & Total \\
\hline Middle Eastern & 0 & 0 & 18 & 2 & 20 \\
\hline China & 0 & 8 & 10 & 2 & 20 \\
\hline
\end{tabular}

Table 7: Ability to write an accuracy and correct statement

As referred to Table 7, approximately all the Middle Eastern respondents in which 18 of them agree that they can write an accuracy and correct statement. China respondents demonstrate that 10 of them can form accurate and correct statement in writing whereas there are 8 of them unable to do so as the logical problems showed by China respondents which consists of the ellipsis of logical connections and conjunctions in sentences (Li, 2002; Liu \& Guo, 2013), the weaknesses and insufficiency in reasoning and argumentations (Li, 2002) and the inconsistency in the linking of ideas in paragraph (Wang, 2009a; Wei, 2010; Wu, 2001). Moreover, China EFL learners have difficulties to explain and argue personal statement effectively, provide sufficient and persuasive information to support opinions and ideas and organize language chunks to construct smoothly-flowing structures in writing (Li, 2002; Li \& Guo, 2013; Wang, 2009a; Wei, 2010; Wu, 2001).

\begin{tabular}{|l|c|c|c|c|c|}
\hline $\begin{array}{l}\text { Question 8: Do you write } \\
\text { your main idea in using } \\
\text { direct format, yet it is } \\
\text { related to the point? } \\
\text { (Thesis statement at the } \\
\text { beginning and supporting } \\
\text { details arranged } \\
\text { hierarchically) }\end{array}$ & $\begin{array}{l}\text { Strongly } \\
\text { Disagree }\end{array}$ & Disagree & Agree & $\begin{array}{c}\text { Strongly } \\
\text { agree }\end{array}$ & Total \\
\hline Middle Eastern & 0 & 2 & 18 & 0 & 20 \\
\hline China & 0 & 7 & 12 & 1 & 20 \\
\hline
\end{tabular}

Table 8: The main idea is written using direct format and it is related to the point

As depicted in Table 8, 18 Middle Eastern respondents reveal that they can write the direct main idea and it is related to the title. Correspondingly to China respondents, the findings highlighted that 12 of them agree with their ability to convey the correct main idea whereas they are 7 of them disagree with the statement. 

DEVELOPMENT

Vol. 8, No. 3, 2019, E-ISSN: 2226-6348 @ 2019 HRMARS

\begin{tabular}{|l|c|c|c|c|c|}
\hline $\begin{array}{l}\text { Question 9: Do your } \\
\text { written discourse is } \\
\text { linear, } \\
\text { using } \\
\text { sequential } \\
\text { systematic } \begin{array}{r}\text { and } \\
\text { (Logically } \\
\text { and } \\
\text { directly related to } \\
\text { the information) }\end{array}\end{array}$ & $\begin{array}{c}\text { Strongly } \\
\text { Disagree }\end{array}$ & Disagree & Agree & $\begin{array}{c}\text { Strongly } \\
\text { agree }\end{array}$ & Total \\
\hline Middle Eastern & 0 & 12 & 8 & 0 & 20 \\
\hline China & 0 & 5 & 14 & 1 & 20 \\
\hline
\end{tabular}

Table 9: Written discourse is linear, sequential and systematic

Table 9 above clearly delineates that there are a total 12 of Middle Eastern respondents who disagree that their written discourse is linear, sequential and systematic way whereas 8 of them agree in doing so. According to Kaplan (1966), he advocated that 12 Middle Eastern respondents disagree about this statement as he proposed that western people especially English speakers use mainly linear paragraph organization in expository texts. In addition, Noor (2001) mentioned that a distinct and non-linear organization of paragraphs in expository prose has shown by other languages such as Middle Eastern learners as they tend to elaborate introductions with less consistent conclusions.

China respondents record the highest amount as 14 of them agree with the systematic way of written discourse and only 5 of them discord commonly about this statement because Chinese writing is different compared to English writing as it is straight linear style (Shen, 1989). It can be further explained as China learners often start with an explanation of conditions and they only get to the real target after clearing the surroundings (Stapleton, 2014). Therefore, some of the China learners apparently produce writing in a curvy way.

\begin{tabular}{|l|c|c|c|c|c|}
\hline $\begin{array}{l}\text { Question 10: Do you use } \\
\text { deductive style (starts } \\
\text { with a general statement } \\
\text { before reach a specific or } \\
\text { logical conclusion) in } \\
\text { English essay writing? }\end{array}$ & $\begin{array}{l}\text { Strongly } \\
\text { Disagree }\end{array}$ & Disagree & Agree & $\begin{array}{c}\text { Strongly } \\
\text { agree }\end{array}$ & Total \\
\hline Middle Eastern & 0 & 8 & 9 & 3 & 20 \\
\hline China & 1 & 6 & 11 & 2 & 20 \\
\hline
\end{tabular}

Table 10: Usage of deductive style in English essay writing

Based on the finding, it portrays that a total number of 12 of the Middle Eastern respondents disagree to apply this style in their English essay writing whereas 8 of them agree in utilizing this pattern.

Besides, the researcher found out that China respondents record the highest percentage is which 11 of them agree in adopting the deductive style in their English essay writing whereas 6 of them disagree to do so. Shen (1989) claimed about Kaplan's seminal paper in 1966 on contrastive 
Vol. 8, No. 3, 2019, E-ISSN: 2226-6348 @ 2019 HRMARS

rhetoric by saying that the Chinese writing follows the Confucian style of first starting the conditions of composition: how, why and when the piece is being composed and this will serve as a proper foundation on which to build a house which thus can be explained about the disagreement of China respondents in using deductive style. It can be further explained as Chinese writing is inductive and English writing is deductive (Stapleton, 2002. p.180). Moreover, Hinds (1990) gave the same opinion as he did research on expository writing in Japanese, Chinese, Korean and Thai. He thus made a conclusion that the inductive approach used by Oriental writers whereas deductive writing preferred to use by English speakers.

\begin{tabular}{|l|c|c|c|c|c|}
\hline $\begin{array}{l}\text { Question 11: Is your } \\
\text { writing format usually } \\
\text { and } \\
\text { repetition } \\
\text { redundancy (excess)? }\end{array}$ & $\begin{array}{l}\text { Strongly } \\
\text { Disagree }\end{array}$ & Disagree & Agree & $\begin{array}{c}\text { Strongly } \\
\text { agree }\end{array}$ & Total \\
\hline Middle Eastern & 8 & 8 & 4 & 0 & 20 \\
\hline China & 2 & 8 & 7 & 3 & 20 \\
\hline
\end{tabular}

Table 11: The repetition and redundancy of writing format

As regards to writing format, Table 11 indicates that majority of the Middle Eastern respondents disagree to use repetition and redundancy format in their writing and only minority of them agree with it in which the minority results can be thus elucidated by Almehmadi (2012) that Middle Eastern writers have tended to use long sentences, repetition, presentation, and elaboration. Repetition is presented by writing more synonyms in the same sentence that in order to demonstrate the eloquence of writer and the stresses of an idea, Middle Eastern speakers accept the usage of synonyms repeated in one sentence. For instance, some phrases could be repeated twice in one sentence such as the phrases "demolition and destruction". Additionally, they often use coordinating conjunctions "and" and "as" excessively, which are corresponding to "wa" and "fa" in the Middle Eastern. Moreover, Middle Eastern speakers also found out that they use much more redundancy in their writing compared to English speakers in which might be attributed to the distinct writing styles of two languages. Therefore, it leads to an overuse of redundancy when native Middle Eastern speakers compose in English.

Unlike Middle Eastern respondents, China respondents present similar results as half of them disagree to utilize this repetition format whereas another half of them agree to adopt it. China respondents that agree with this assertion because they believed that Chinese EFL writers use a variety of repetition forms to achieve cohesion (Hoey \& Zhu, 2001). These researchers found out that most of the Chinese EFL learners especially in both Chinese intermediate and advanced EFL non-English major Ph.D. learners tend to use redundant and empty words to repeat both meaning and form on either sentence level or textual level. 
INTERNATIONAL JOURNAL OF ACADEMIC RESEARCH IN PROGRESSIVE EDUCATION AND DEVELOPMENT

Vol. 8, No. 3, 2019, E-ISSN: 2226-6348 @ 2019 HRMARS

\begin{tabular}{|l|c|c|c|c|c|}
\hline $\begin{array}{l}\text { Question 12: Do the } \\
\text { words you are using } \\
\text { usually tied to emotions } \\
\text { while an essay? }\end{array}$ & $\begin{array}{l}\text { Strongly } \\
\text { Disagree }\end{array}$ & Disagree & Agree & $\begin{array}{c}\text { Strongly } \\
\text { agree }\end{array}$ & Total \\
\hline Middle Eastern & 0 & 7 & 11 & 2 & 20 \\
\hline China & 0 & 4 & 14 & 2 & 20 \\
\hline
\end{tabular}

Table 12: Usage of words tied to emotions while writing an essay

Regarding the respondents' using words that tied to their emotions as referred to Table 12 , there are approximately more than half of the Middle Eastern respondents which is total 13 of them agree that they are influenced by their emotions while writing an essay and 7 of them disagree with it. Al-Khatib (2001) stated that persuasion in the Middle Eastern is structural and rulegoverned and it is based on three major modes which are trustworthiness, argumentation and appeal to emotion which is thus explained the finding of this result. By asserting their trustworthy and reliability at the beginning for persuaders to convince readers. Second, Middle Eastern learners will give an opinion and support it by giving convincing reasons. Then, persuaders may appeal to the audience emotionally as it is often used with religion, proverbs, and wisdom which refers to the sayings and lines of the verse. These three modes work together as revealed by AlKhatib's study.

Like Middle Eastern respondents, 14 China respondents agree that they often used words that tied with their feelings in their writing and 4 of them disagree in supporting this statement. Therefore, according to the finding presented by a majority of the China respondents agree with this statement, Williams (2007) claimed that writing is a multidimensional communicative process which cares about the generation, analysis, and synthesis of ideas; the organization of discourse; the control of sentence structure; the lexicons, spelling, and mechanics. In other words, it can be explained that writing is related to emotions, knowledge, inspiration, logical reasoning, linguistic skills, and contextual adaption.

\begin{tabular}{|l|c|c|c|c|c|}
\hline $\begin{array}{l}\text { Question 13: Do you use } \\
\text { parallelism (similar parts of a } \\
\text { sentence that have the same } \\
\text { structure) and comparison } \\
\text { to illustrate your ideas? }\end{array}$ & $\begin{array}{l}\text { Strongly } \\
\text { Disagree }\end{array}$ & Disagree & Agree & $\begin{array}{c}\text { Strongly } \\
\text { agree }\end{array}$ & Total \\
\hline Middle Eastern & 0 & 0 & 11 & 9 & 20 \\
\hline China & 1 & 4 & 13 & 2 & 20 \\
\hline
\end{tabular}

Table 13: Usage of parallelism and comparison to illustrate ideas

Data gathered as shown in Table 13 displays that a total of 20 Middle Eastern respondents agree that they use parallel and comparison format to explain their ideas. Koch (1983) conducted a study to analyse English essays by Middle Eastern-speaking English learners and he found out that majority of the learners made extensive use of devices such as parallelism and repetition of the most influential words and phrases. 
Vol. 8, No. 3, 2019, E-ISSN: 2226-6348 @ 2019 HRMARS

As for China respondents, 13 of them agree to use contradistinction to express their thoughts whereas there are total 5 of them disagree of using this format. The disagreement from China respondents showed that they seldom utilize this way to express their ideas. Majority of the China EFL learners only able to write sentences correctly in grammar as when it compares to professors, they can make the whole sentence structure prettier and China learners unable to do it. Therefore, some China EFL learners only able to illustrate their ideas in plain sentences.

\begin{tabular}{|l|c|c|c|c|c|}
\hline $\begin{array}{l}\text { Question 14: Do you } \\
\text { have the tendency to } \\
\text { use long sentences in } \\
\text { writing an essay? }\end{array}$ & $\begin{array}{l}\text { Strongly } \\
\text { Disagree }\end{array}$ & Disagree & Agree & $\begin{array}{c}\text { Strongly } \\
\text { agree }\end{array}$ & Total \\
\hline Middle Eastern & 0 & 15 & 4 & 1 & 20 \\
\hline China & 2 & 11 & 8 & 1 & 20 \\
\hline
\end{tabular}

Table 14: The tendency to use long sentences in writing an essay

Table 14 reveals that 15 of Middle Eastern respondents disagree that they tend to use long sentences while writing an essay and only with a total of 4 of them agree with this declaration. However, this finding different with the previous results as claimed by Al-Khatib (2001) that Middle Eastern EFL learners tend to write long sentences with coordinating conjunctions, repeat the sentences and use presentation and elaboration in order to persuade the readers (Almehmadi, 2012). Furthermore, Al-Khatib (2001) conducted a related study by determining that Middle Eastern learners' sentences are very long while they are required to write letters in English.

Furthermore, alike with Middle Eastern respondents, China respondents also record the highest result in disagreement about the usage of long sentences in writing essay whereas the remaining 9 of them agree to do so. The agreement by a minority in this statement because China writers often translate the sentences directly from Chinese to English. The writing from China writers and English writers are distinct as Chinese writing usually put in several supporting ideas in sentences to demonstrate the relationship whereas the main idea and each supporting idea in English writing usually written in separate sentences. 
Vol. 8, No. 3, 2019, E-ISSN: 2226-6348 @ 2019 HRMARS

\begin{tabular}{|c|c|c|c|c|c|}
\hline $\begin{array}{l}\text { Question 15: Do you } \\
\text { use intuition reasoning } \\
\text { as it means to start with } \\
\text { a vague (unclear) idea } \\
\text { and your ideas turn into } \\
\text { something interesting } \\
\text { but at the beginning, } \\
\text { you do not know where } \\
\text { your writing is going? }\end{array}$ & $\begin{array}{l}\text { Strongly } \\
\text { Disagree }\end{array}$ & Disagree & Agree & $\begin{array}{c}\text { Strongly } \\
\text { agree }\end{array}$ & Total \\
\hline Middle Eastern & 0 & 6 & 13 & 1 & 20 \\
\hline China & 1 & 3 & 15 & 1 & 20 \\
\hline
\end{tabular}

Table 15: Usage of intuition reasoning

The finding of the usage of intuition reasoning is shown in Table 15. Total of 14 Middle Eastern respondents illustrated agreement to this statement whereas 6 of them disagree with it.

As comparable to Middle Eastern respondents, China respondents also depict approximately the same results in which total of 16 of them consent to the utilization of intuition reason in writing whereas total 4 of them indicate contradict opinions.

\section{Discussions}

\section{Language Pattern}

Crosstabulation has been utilised in order to determine the educational level and writing patterns of the Middle Eastern and China EFL learners. Furthermore, crosstabulation is used to examine the significant result between the educational level and writing patterns of both EFL learners.

According to Kaplan (1966), he stated that Asian Discourse Pattern utilised by China EFL learners whereas Arab Semitic Pattern adopted by Middle Eastern EFL learners. However, this assertion has been denied in this study which has been discussed in Table 33 as it highlighted only a slightly significance result between these linguistic group with their writing patterns.

Apart from that, there are a total of $40 \mathrm{EFL}$ learners in which 20 of them are from Middle Eastern and the remaining 20 of them from China. However, among these $40 \mathrm{EFL}$ respondents, they have different educational level. There are 20 Middle Eastern EFL learners in which 19 of them are Master learners and only 1 of them is a Ph.D. learner. In contrast, among China EFL learners, all of them have the same educational level as Degree learners at the moment. Therefore, due to the different educational level among the Middle Eastern and China EFL learners in this study, it is thus aimed to scrutinize whether the effect of different educational level influence both EFL learners' writing patterns in academic writing.

In this section, only the option "Strongly Agree" is adopted among the Likert Scale as it enables the researcher to focus on the best option that strongly indicated the writing patterns of Middle Eastern and China EFL learners. Besides, the Count listed in the table is identified as the frequency 
of both Middle Eastern and China EFL learners in ticking "Strongly Agree" but not represents the number of respondents.

Furthermore, it delineated that the rate of using Arab Semitic Pattern in their academic writing is 9 times (45\%) demonstrated by China EFL learners who are Degree learners at the same time. This result obtained from Arab Semitic Pattern presented that China EFL learners utilised this pattern as well as Asian Discourse Pattern in their academic writing as both patterns have similar rates. Besides, Romance Language Pattern revealed the lowest rate with only 8 times (40\%) used by Degree learners in academic writing. Surprisingly, Degree learners elucidated the highest rate of Russian Language Pattern, 13 times (65\%) by applying it in their academic writing.

On the other hand, for Middle Eastern EFL learners, as in currently there are only 1 respondent is pursuing Doctor of Philosophy (Ph.D.), the result presented might be extreme compared to the others 19 Master learners. As referred in Table 35, Master learners from Middle Eastern presented the rate, 8 times (36.8\%) by using Asian Discourse Pattern in their academic writing whereas the rate for using this pattern recorded by the only one Ph.D. learner is 1 time (100\%). Similar to Degree learners from China, the rate recorded for Middle Eastern EFL learners that studying Master in present is 4 times (21.1\%) adopt English Language Pattern in their academic writing in which this finding differs with the result obtained in Table 34 that Middle Eastern learners utilised English Language Pattern the most.

Apart from that, the highest rate is highlighted in using Arab Semitic Pattern by both Master and Ph.D. learners from Middle Eastern in which Master learner depicted 11 times (57.9\%) whereas the Ph.D. learner portrayed 2 times (40\%) by utilising this pattern in academic writing as these 5 questions designed accordingly to Arab Semitic Pattern and the Ph.D. learner in specifically has ticked twice column (40\%) on Strongly Agree for the questions of Arab Semitic Pattern. Thus, it can be summarized that Master and Ph.D. learners mostly adopted Arab Semitic Pattern in their academic writing. In addition, Romance Language Pattern and Russian Language Pattern depicted the same rates which are $5.3 \%$ and $100 \%$ by Master and Ph.D. learner respectively in both writing patterns. In a nutshell, it can be concluded that the significant result is shown regarding the educational level influence the writing patterns (Arab Semitic Pattern) of Middle Eastern EFL learners in academic writing whereas only a slightly significance result is shown between the educational level of China EFL learners with their writing patterns (Asian Discourse Pattern) in academic writing.

\section{Conclusion}

From the research findings, it can be concluded that both the Middle Eastern and China EFL learners have presented a slight significance result between their cultures and writing patterns. Kaplan (1966) defined Cultural Thought Patterns by stating that contrastive rhetoric referred to each language and each culture a paragraph order unique to itself and thus it demonstrated that different organizational patterns shown by the texts written in different languages as a result of differences in the cultural dimension. This phenomenon can be thus elucidated by Kaplan that the rhetorical strategies used in a learner's essay writing in English affected by the rhetorical 
strategies associated with the learner's native culture. Contrastive rhetoric apparently can describe the findings as both the Middle Eastern and China EFL learners did present the traits of their particular writing patterns, however, in order to explain in details, the writing patterns of both the Middle Eastern and China EFL learners recorded the highest records in the writing patterns of English native speakers and only related to some components of the Romance and Russian Language Patterns. In other words, it indicated that the culture of Middle East EFL learners does not show the significant result in using Arab-Semitic Pattern whereas the culture of China EFL learners does not reveal significant result in utilizing Asian Discourse Pattern.

Apart from that, according to the perspectives from both of the Middle East and China EFL learners, it can be seen that Middle East EFL learners usually did writing in research papers as during the data collection, researcher had opportunity to have conversation with them to have deeper understanding towards them as they stated about they read plenty of journals in order to write research papers due to the reason that majority of them are Master learners. On the other hand, writing of China EFL learners usually influenced by their native language in which it causes them to think about their mother tongue every time while writing English and thus having trouble in transmitting ideas.

Lastly, educational level is one of the factors that influence EFL learners' writing patterns in which the result is clearly depicted on Middle Eastern EFL learners as they did use Arab Semitic Pattern the most in their academic writing. However, the significance result did not demonstrate on China EFL learners as only part of them utilise Asian Discourse Pattern that caused only slightly significance result is shown.

\section{References}

Al-Khatib, A. M. (2000). The Arab world: Language and cultural issues. Language, Culture and Curriculum, 13 121-125.

Almehmadi, M. M. (2012). A Contrastive Rhetorical Analysis of Factual Texts in English and Arabic 3: 68-76.

Alsamadani, H. A. (2010). The relationship between Saudi EFL students' writing competence, L1 writing proficiency, and self-regulation. European Journal of Social Sciences, 16(1), 53-63.

Ariyanti, A. (2017). Foreign Language Anxiety in Academic Writing. Dinamika Ilmu 17(1): 143. doi:10.21093/di.v17i1.815

Bakker, B. F. M. (1985). Sociaal milieu en cultuurdeelname: Een nadere toetsing van Ganzebooms infor- matietheorie [Socio-economic background and cultural participation]. Mens en Maatschappij 60, 162-177.

Bowen, Tim, \& Marks, Jonathan. (1994). Inside teaching: options for English language teachers (Vol. Teacher development series). Oxford: Heinemann.

Cai, G. (1993). Beyond "bad writing"; Teaching English composition to Chinese ESL students. Paper presented at the Conference on College Composition and Communication, San Diego, April, 1993. 
INTERNATIONAL JOURNAL OF ACADEMIC RESEARCH IN PROGRESSIVE EDUCATION AND DEVELOPMENT

Vol. 8, No. 3, 2019, E-ISSN: 2226-6348 @ 2019 HRMARS

Casanava, C. P. (2003) Looking ahead to more sociopolitically-oriented case study research in L2 writing scholarship (But should it be called "post-process"?) Journal of Second Language Writing 12, 85-102.

Connor, U. (1996). Cross cultural aspects of second language writing. Cambridge: Cambridge University Press.

Crystal, D. (1997). English as a Global language. Cambridge: Cambridge University Press.

Denscombe, M. (1998). The Good Research Guide. Buckingham. Open University Press.

Dickins, J. \& Waston, J. C. E. (1999). Standard Arabic: An Advanced Course. Cambridge, UK: Cambridge University Press.

Feghali, E. (1997). Arab cultural communication patterns. International Journal of Intercultural Relations, 21 (3), 345-378.

Farghal, M., \& Shunnaq, A. (1999). Translation with reference to English and Arabic: A practical guide. In D. Al-Hilal (Trans.). Irbid. Jordan.

Ganzeboom, H. (1989). Cultuurdeelname in Nederland. Assen: Van Gorcum

Grabe, W., \& Kaplan, R. B. (1989). Writing in a second language: Contrastive rhetoric. In D.M. Johnson \& D.H. Roe-n (Eds.), Richness in writing: Empowering ESL students (pp. 263-283). White Plains, NY Longman.

Gu, H. Y. (1992). Drawing the dragon: Chinese rhetoric for ESL teachers. Unpublished master's thesis. St. Cloud State University, St. Cloud, Minnesota.

Hinds, J. (1990). Inductive, deductive, quasi-inductive: Expository writing in Japanese, Korean, Chinese and Thai. In U. Connor \& A. Johns (Eds.), Coherence in writing: Research and pedagogical perspectives (pp. 87-110). Alexandria, VA: TESOL

Hoey, M. (2001). Patterns of lexis in text. Shanghai: Shanghai Foreign Language Education Publishers.

Jia, Y. (1997). Intercultural communication. Shanghai: Shanghai Foreign Language Education Press

Hyland, K. (2003). Second language writing. Cambridge: Cambridge University Press.

Kaplan, R. (1966). Cultural thought patterns in intercultural education. Language Learning, 16, 120.

Kaplan, R. (1972). The anatomy of rhetoric: prolegomena to a functional theory of rhetoric. Philadelphia: Center for Curriculum Development (Concord, Massachusetts: Heinle and Heinle).

Kaplan, R. (1983). Contrastive rhetorics: Some implications for the writing for the writing process. In A. Freedman, I. Pringle \& J. Yalden, (Eds.), Learning to write: First language/second language (pp. 139-161). New York: Longman Group Ltd.

Kaplan, R. (1987). Cultural thought patterns revisited. In R. Kaplan \& U. Connor (Eds.), Writing across languages: Analysis of L2 text (pp.9-22). Reading, MA: Addison-Wesley

Kaplan, R. (1988). Contrastive rhetoric and second language learning: Notes toward a theory of contrastive rhetoric. In A. Purves (Ed.), Writing across languages and cultures. Issues in contrastive rhetoric (pp. 275-304). Newbury Park, CA: Sage.

Kellogg, R. T. \& Raulerson, B. A. (2007). Improving the writing skills of college students. Psychonomic Bulletin and Review 14(2): 237-242. doi:10.3758/BF03194058 
INTERNATIONAL JOURNAL OF ACADEMIC RESEARCH IN PROGRESSIVE EDUCATION AND DEVELOPMENT

Vol. 8, No. 3, 2019, E-ISSN: 2226-6348 @ 2019 HRMARS

Khuwaileh, A., \& Shoumali, A. (2000). Writing errors: a study of the writing ability of Arab learners of academic English and Arabic at university. Language, Culture and curriculum, 13(2), 174-183.

Koch, B. J. (1983). Presentation as proof: The language of Arabic rhetoric. Anthropological Linguistics, 25(1), 47-60.

Kroll, B. (1990). Second language writing. Cambridge: Cambridge University Press.

Leedy, P. \& Ormrod, J. (2001). Practical research: Planning and design (7th ed.). Upper Saddle River, NJ: Merrill Prentice Hall. Thousand Oaks: SAGE Publications.

Lian, S. (1993). Contrastive studies of English and Chinese. Beijing: Higher Education Publisher.

Liebman, J. D. (1992). Toward a New Contrastive Rhetoric: Differences Between Arabic and Japanese Rhetorical Instruction 141-165.

Li, C. Z. (2002). Yupian de xianjie, lianguan, yu daxue yingyu xiezuo [The coherence and cohesion in discourses in undergraduate English writing]. Foreign Languages and Their Teaching, 164(11), 25-28.

Liu, Chendan. \& Zhao, X. (2011). What is text linguistics. Shanghai: Shanghai Foreign Language Education Press.

Liu, J. L., \& Guo, P. J. (2013). Qiantan daxuesheng yingyu zuowen zhong de luoji lianjie cuowu [An analysis of the incoherence and incohesion in Undergraduate English writing]. Shanxi shida xuebao [Journal of Shaanxi Normal University], 40, 153-156.

Matalene, C. (1985). "Contrastive rhetoric: An American writing teacher in China." College English, 47(8), 789-808.

Mohan, B. A., \& Lo, W. A. (1985). Academic writing and Chinese students: Transfer and developmental factors. TESOL Quarterly, 19 (3), 515-534.

Noor, R. (2001). Contrastive rhetoric in expository prose: Approaches and achievements. Journal of Pragmatics, 33, 255-269.

Ostler, S. E. (1987). English in parallels: A comparison of English and Arabic prose. In U. Connor \& R.B. Kaplan (Bds.), Wriring ucross languages: Analysis ofL2 rexr (pp. 169-185). Reading, MA: Addison-Wesley.

Parahoo K. (1997). Nursing research: principles, process and issues. Basingstoke: Macmillan;

Pesola, C. (1991). Culture in the elementary school foreign language classroom. Foreign Language Annals 24(4), 331-346.

Quinn, J. M. (2012). Using contrastive rhetoric in the ESL classroom. Teaching English in the TwoYear College, 40(1), 31-38

Sa'adeddin, M. A. (1989). Text development and Arabic-English negative interference. Applied Linguistics. 10 (1). Pp.36-51.

Shen, F. (1989). The classroom and the wider culture: Identity as a key to learning English composition. College Composition \& Communication, 40(4), 459-466.

Sidek, H. M. (2012). Efl Reading Instruction: Communicative Task based Approach. International Journal of Instruction, 5, 109-128.

Smith, B. (2001). Learner English: A teacher's guide to interference and other problems. United Kingdom: United Kingdom Press

Snively, H. (1999). Coming to Terms with Cultural Differences: Chinese Graduate Students Writing Academic English (pp. 26-31). Ph. D dissertation, Harvard University. 
Stapleton, P. (2002). Critiquing voice as a viable pedagogical tool in L2 writing: Returning the spotlight to ideas. Journal of Second Language Writing, 11, 177-190.

Stapleton, P. (2014). Critical thinking in Japanese L 2 writing: rethinking tired constructs (July 2002). doi:10.1093/elt/56.3.250

Swales, J., and Mustafa, H. (Eds.). (1984). English for Specific Purposes in the Arab World. Birmingham: The University of Aston.

Wang, S. W. (2009a). Yupian xianjie de cuowu fenxi jiqi dui xiezuo jiaoxue de qishi: Yixiang jiyu daxue yingyu siji kaoshi xiezuo bufen de diaocha [The incoherence in undergraduate English writing and its implication to English writing education: A research based on the writing test in CET-4]. Master, 139-140.

Wei, X. Q. (2010). Lun Boke yingyong yu daxue yingyu xiezuo jiaoxue [Weblog in teaching college English writing]. Journal of Xinjiang Normal University, 31(2), 125-132.

William. G. (2007). Reading in a Foreign Language. Graphic organizers in reading instruction: Research findings and issues.

Wu, M. Z. (2001). Daxue yingyu xiezuo wenti yu duice tantao [Problems in undergraduate English writing and possible solutions]. Journal of Yangzhou University, 5(1), 66-69

Zhu, Y, Zheng, L., \& Miao, X. (2001). Reflection of systematic functional languages. Shanghai: Shanghai Foreign Language Education Publishing House. 